\title{
LATE PLEISTOCENE CLIMATE CHANGE AND EROSION IN THE SANTA MARIA BASIN, NW ARGENTINA
}

\author{
MARTIN H. TRAUTH, BODO BOOKHAGEN, ANDREA B. MÜLLER, AND MANFRED R. STRECKER \\ Institut für Geowissenschaften, Universität Potsdam, POB 601553, D-14415 Potsdam, Germany \\ e-mail: trauth@geo.uni-potsdam.de
}

\begin{abstract}
Aвstract: Present erosion and sediment flux in the semiarid intramontane Santa Maria Basin, NW Argentina, are compared with conditions during a period of wetter and more variable climate at about $30,000{ }^{14} \mathrm{C}$ yr ago. The results suggest that the influence of climate change on the overall erosional sediment budget is significant, mainly because of a change in the erosion regime coupled with an increase in mass movements. The most effective mechanism to increase landslide activity in this environment is a highly variable climate on interannual timescales. In contrast, Quaternary changes in erosional budgets due to variations in moisture regimes is small in the Santa Maria Basin. Because the magnitude of a potential increase in background erosion as well as enhanced landsliding is smaller than typical levels of uncertainty of erosional budgets for such large basins, it is not likely that climate-driven erosional unloading can influence tectonic style and rates in this semiarid environment on time scales of several thousands to a few tens of thousands of years.
\end{abstract}

\section{INTRODUCTION}

The interaction of tectonics and climate regarding the evolution of topography is a matter of debate (Small 1999). The history of many Cenozoic orogens demonstrates how the creation of high relief profoundly influences climate; examples include the uplift of the Tibetan Plateau and its influence on the westerlies and the monsoon system, or the evolution of the PunaAltiplano plateau on the position and seasonal migration of the Intertropical Convergence Zone (ITCZ) (e.g., Molnar et al. 1993; Raymo and Ruddiman 1992; Raymo 1994). On the basis of modeling results, feedback among orogenic activity, erosion, isostasy, and climatic change has also been proposed (e.g., Molnar and England 1990; Bull 1991; Mulder and Syvitski 1996; Whipple et al. 1999; Willett et al. 2001). Molnar and England (1990) initially argued that accelerated rates of Quaternary tectonism might in fact be produced by a more erosive climate and hence an increase in topographic relief. In contrast, Whipple et al. (1999) suggest that climate change may cause increased erosion in tectonically active mountain ranges, but neither fluvial nor glacial erosion is likely to induce significant isostatic uplift of mountain peaks. Only a few field studies have actually documented significant changes due to Quaternary climatic fluctuations such as glacialinterglacial transitions in higher latitudes or periods of increased humidity (Ruddiman 1997). In tropical and subtropical regions, the impact of the El Niño/Southern Oscillation (ENSO) may have further important influences on the volumes and rates of mass transfer. In mountainous regions, extreme ENSO events are known to trigger catastrophic mass movements and cause highly variable erosion rates and sediment yields (Grosjean et al. 1997; Keefer et al. 1998; Keefer 1999; Trauth et al. 2000).

In this paper we present a sediment budget for the semiarid Santa Maria Basin in the NW Argentine Andes during the Minchin wet period (40,000 and $25,000{ }^{14} \mathrm{C}$ yr BP) (Fig. 1). Compared to the present, this interval was characterized by increased humidity (Fox and Strecker 1991; van der Hammen and Absy 1994; Wirrmann and Mourguiart 1995; Ledru et al. 1996; Godfrey et al. 1997; Turcq et al. 1997; Haselton et al. 2002) and a stronger ENSO influence (Trauth et al. 2000; Beaufort et al. 2001; Tudhope et al. 2001) (Fig. 1). During this time period, the NW Argentine Andes experienced more frequent catastrophic mass movements with volumes in excess of $10^{6} \mathrm{~km}^{3}$ each (Hermanns and Strecker 1999; Strecker and Marrett 1999; Trauth and Strecker 1999; Hermanns et al. 2000; Trauth et al. 2000). More- over, at this time, the catchment of the Santa Maria Basin, $19,760 \mathrm{~km}^{2}$ in area, was hydrologically and sedimentologically closed by a catastrophic rock avalanche (Trauth and Strecker 1999; Bookhagen et al. 2001), and the resulting paleo-Lake Santa Maria formed an effective sediment trap. Mechanical denudation rates in the catchment of such a closed basin can be calculated by computing the sediment volume deposited during a defined time span and relating it to the catchment area (e.g., Einsele and Hinderer 1998). Comparing the denudation rates during this period with present-day values can provide insights into the contrasts in magnitude and variability of erosion and sedimentation between climate regimes, as they change through time, in one of the largest intramontane basins of the Central Andes. Moreover, this work may contain valuable new steps towards a quantitative methodology including an assessment of the errors while calculating erosional budgets.

\section{SETTING}

The Santa Maria Basin is bounded by reverse and thrust faults that have been active throughout late Cenozoic time (Strecker et al. 1989; Grier et al. 1991). The surrounding mountains are in excess of $5000 \mathrm{~m}$ high and dominated by low-grade metamorphic rocks and Paleozoic granites, as well as Mesozoic sandstones and conglomerates. Basin sediments consist of reddish Neogene sandstones and siltstones, which are unconformably overlain by Quaternary gravels, lake sediments, and landslide deposits (Bossi and Palma 1982; Strecker et al. 1989; Grier et al. 1991). The basin margins and the outlet area are characterized by multiple landslide deposits (Hermanns and Strecker 1999; Strecker and Marrett 1999; Hermanns et al. 2000). The most prominent landslide in the Santa Maria Basin occurs along the Rio Las Conchas, which drains this depression to the east below the confluence of the allochthonous Calchaqui and Santa Maria rivers at an elevation of $1500 \mathrm{~m}$. Around $30,000{ }^{14} \mathrm{C}$ yr BP, landslide debris completely blocked the Rio Las Conchas, resulting in a lake that occupied the valley up to the $1700 \mathrm{~m}$ contour and covered an area of about $630 \mathrm{~km}^{2}$ (Trauth and Strecker 1999; Trauth et al. 2000; Bookhagen et al. 2001).

The up to 40-m-thick deposits of this lake consist mainly of laminated buff-colored clay and silt. AMS- ${ }^{14} \mathrm{C}$ dating of rare carbonate bivalves (Spaerium sp.) sampled in the upper part of the lake-sediment sequence provides an age of 28,990 $\pm 150{ }^{14} \mathrm{C}$ yr BP for these deposits (Trauth and Strecker 1999; Trauth et al. 2000). The best preserved laminated lake sediments occur at the location referred to as El Paso, which is close to the landslide dam (Trauth and Strecker 1999) (Figs. 2 and 3). The laminae typically are 1 to $5 \mathrm{~mm}$ thick in the lower parts of the section and up to $10 \mathrm{~mm}$ thick in the higher parts. The base of the mixed clastic and biogenic laminae couplet in this section is typically sharp and consists of reddish silt and clay (Fig. 4). Toward the top of a single couplet, reddish clay and silt are gradually replaced by light-brown to greenish colored clay, and the change from redder hues correlates with a slight decrease in grain size. The clastic part of each couplet is overlain by a thin layer of white diatomite. The internal structure of the laminae, the cyclic recurrence of paired diatomite and clastic layers, the sediment coloration and provenance provide strong evidence that rhythmic sedimentation in this region is controlled by the strong annual cycle in precipitation (Anderson 1996; Trauth and Strecker 1999). This conclusion is also supported by the results from nonlinear timeseries analysis showing significant similarities in the dynamics of modern rainfall data and paleo-precipitation records extracted from the lake sediments (Marwan et al. 2000; Marwan and Kurths 2002). However, we in- 


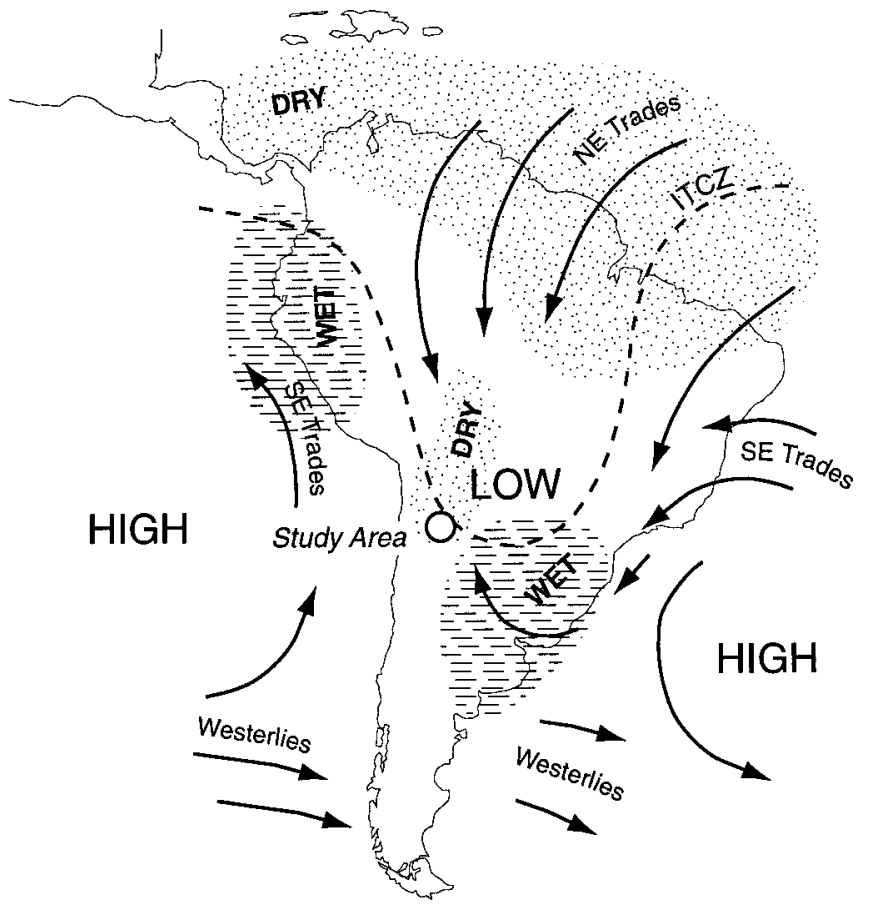

Fig. 1.-Present-day airflow patterns during the summer rainy season and principal areas of rainfall anomalies during El Niño years in South America. Modified from Ropelewski and Halpert (1987) and Kiladis and Diaz (1989).

deed cannot prove these laminae are true varves because the sediments are too old in order to compare absolute dating with laminae counts and/or correlate our chronology with well-dated annual chronologies from other localities.

The present-day climate of NW Argentina is controlled mainly by a seasonal low-pressure system east of the Andes (Fig. 1). During the austral summer, this low-pressure system attracts northeasterly and easterly moisture-bearing winds in the northern part of the region, e.g., Salta, whereas the southeastern parts are dominated by southerly and southwesterly winds, e.g., Tucuman (Prohaska 1976; Hastenrath 1991; Bianchi and Yañez 1992). Precipitation in NW Argentina is highly seasonal, with dry winters (precipitation less than $50 \mathrm{~mm}$ per month) and wet summers (more than 150 $\mathrm{mm}$ ). In the study region, $80 \%$ of annual rainfall falls in the austral summer between November and February (Bianchi and Yañez 1992). Because of the orographic barriers to the east, the intra-Andean basins and valleys are arid and receive less than $200 \mathrm{~mm} \mathrm{yr}^{-1}$ of precipitation (Bianchi and Yañez 1992). These longitudinal and transverse geomorphological depressions develop their own wind systems: predominating winds from the mountains to the plains dominate in the cool season, with the reverse direction dominant in summer (Prohaska 1976).

Interannual variation in the intensity of summer rains appears to be controlled by sea-surface temperatures (SST) of the tropical Atlantic and Pacific Oceans. Of particular importance are decadal variations in the interhemispheric SST gradient across the Equator in the Atlantic, which is also called the Tropical Atlantic SST Variability (TAV) (Enfield and Mayer 1996; Chang et al. 1997). When the cross-equatorial SST gradient is reduced, which corresponds to low TAV amplitudes, the tropical North Atlantic is cool relative to the South Atlantic, resulting in increased surface pressure over the North Atlantic and a southward shift of the ITCZ. This leads to weakening of the SE trades and intensification of the NE trades, with greater precipitation in tropical and subtropical South America. Such changes occur with mean periodicities of 10 to 14 years (Enfield and Mayer 1996; Chang et al. 1997). In our study area, we would expect more rain during such minimum TAV years.

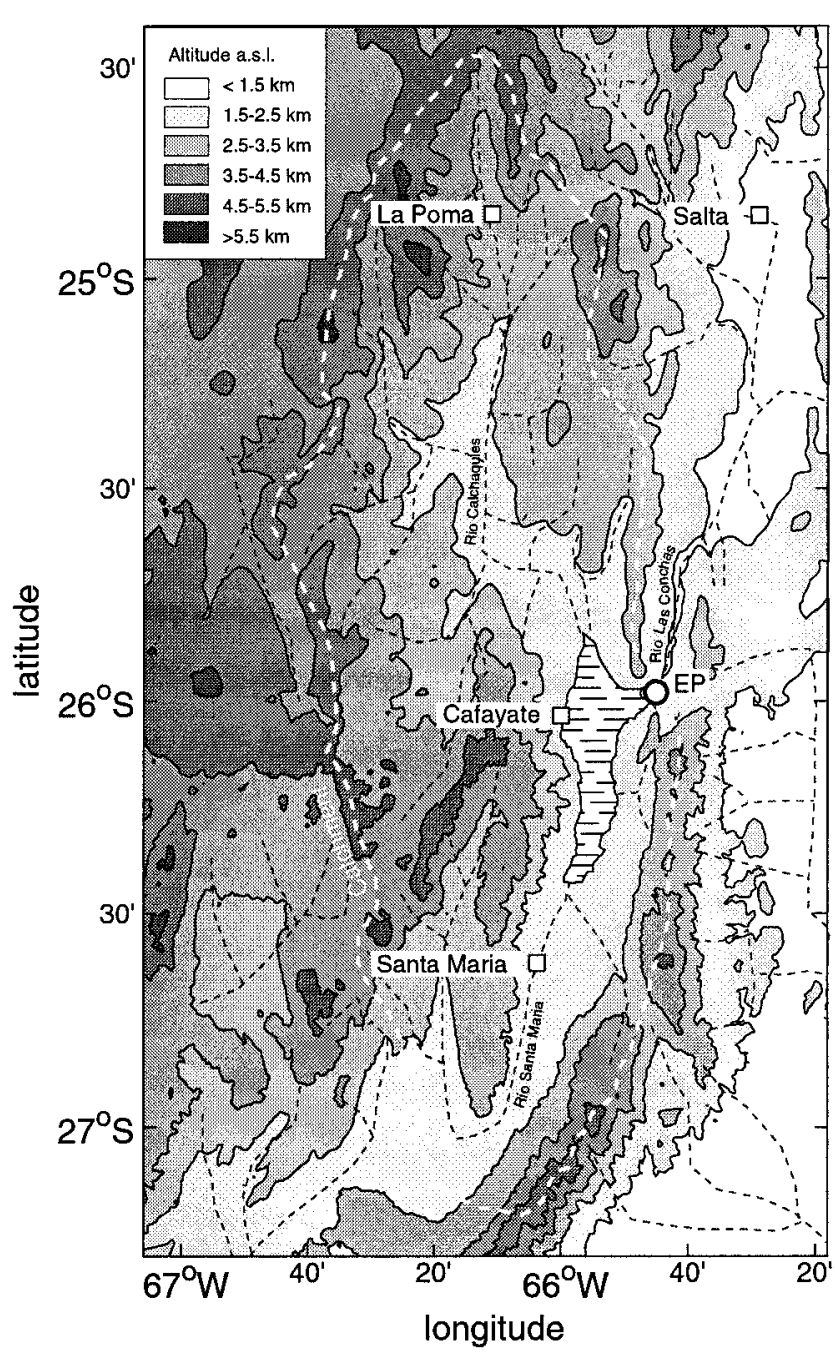

FIG. 2.-Topographic map of the study area showing the paleo-Lake Santa Maria near the town of Cafayate, the catchment area of the Santa Maria Basin (white dashed line) and the extent of the drainage system. East of Cafayate is the location of the El Paso reference section for the lake sediments (EP).

In addition, the amount and distribution of rainfall are influenced by the El Niño/Southern Oscillation (ENSO) (Prohaska 1976; Hastenrath 1991). The ENSO teleconnection results in a complex spatial pattern of rainfall anomalies in South America (Fig. 1). Instrumental records show decreased precipitation over northeastern Brazil, the Amazon Basin, and the Altiplano-Puna plateau at about $3500 \mathrm{~m}$ elevation during the El Niño phase of the ENSO (Ropolewski and Halpert 1987; Enfield and Mayer 1996). During this time, in contrast, increased rainfall occurs in northwestern (Ecuador, northern Peru) and southwestern (Chile) South America, and in southeastern Brazil (Ropolewski and Halpert 1987; Kiladis and Diaz 1989; Bianchi and Yañez 1992). La Niña events cause similar spatial rainfall anomalies but with opposite sign and lower amplitude than El Niño events (Ropolewski and Halpert 1987; Kiladis and Diaz 1989). In NW Argentina, information on the ENSO influence on local rainfall is limited. However, instrumental records from the last decades show a weak but spatially and temporally highly variable tendency toward less rain during El Niño years (Bianchi and Yañez 1992; Trauth et al. 2000).

\section{METHODS}

In the Santa Maria Basin, the 37-m-thick El Paso section is located in the deepest part of the basin $2.5 \mathrm{~km}$ upstream from the landslide dam (Fig. 
El Paso Section Chronology

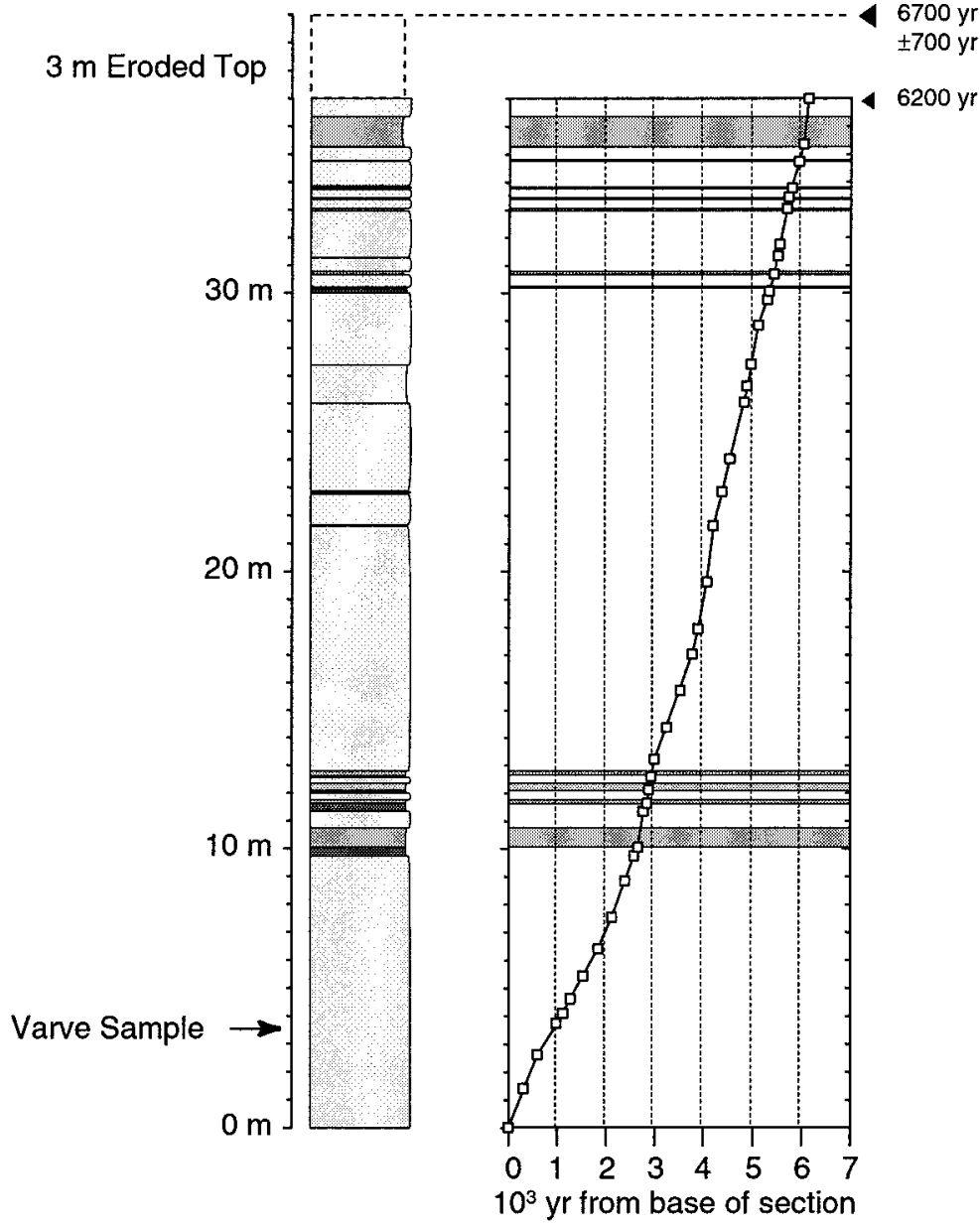

Sedimentation

Rate

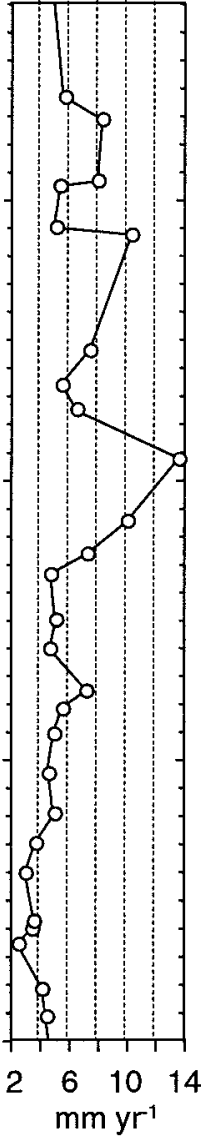

FIG. 3.-Simplified lithology, varve chronology, and sedimentation rates for the $\mathrm{El}$ Paso section in the Santa Maria Basin. Dark gray parts of the profile depict seismites, medium gray parts indicate turbidites, and light gray parts indicate laminated silts and clays.
2). Several continuous, but non-overlapping sections of laminated sediments, 10 to $250 \mathrm{~cm}$ thick, were taken at $3.5 \mathrm{~m}, 5.5 \mathrm{~m}, 13.5 \mathrm{~m}, 27.0 \mathrm{~m}$, and $33.0 \mathrm{~m}$ above the base of the El Paso section for detailed sedimentological analysis. Assuming that the lake sediments consist of annual couplets, the time span of lacustrine sedimentation can be estimated. Varve counts were carried out on high-quality photographs taken from the cleaned sediment surface (Figs. 3 and 4). These counts were cross-checked by counting representative sections in the field or in thin sections. The varve chronology was corrected for disturbances created by turbidites, soft-sediment deformation, and seismites. Sections with equivocal lamination were interpolated linearly using averaged sedimentation rates determined from around 25 varves below and above the corresponding parts of the profile. AMS radiocarbon dates are reported as ${ }^{14} \mathrm{C}$ yr BP (radiocarbon years before present, "present" = $1950 \mathrm{AD}$ ), and calculated using the Libby ${ }^{14} \mathrm{C}$ half life of $5568 \mathrm{yr}$.

Calculations of catchment area and sediment volume are based on a 100 $\mathrm{m}$ digital elevation model (DEM) compiled from maps at a scale of 1:250,000 and 1:25,000. This DEM was compared with the GTOPO30 dataset of the U.S.G.S. Despite their different resolution, the difference between the two DEMs in terms of calculated areas and sediment volumes is less than two percent. In order to determine the volume of the threedimensional sediment body, the erosional remnants of the lacustrine de- posits were mapped using air photos and field observations of crosscutting geomorphic and stratigraphic relations. The top and base of the sediment body were defined using gravels underlying and overlying these sediments, as well as erosional unconformities with subjacent bedrock or older alluvium. The vertical and lateral extent was determined using a Leica total station in the most critical areas as well as GPS measurements. For paleoLake Santa Maria, twenty reference points for the top and base of the lakesediment body were determined in the field (Fig. 5). These reference points were selected after rigorous quality control, i.e., their position and altitude was cross-checked with independent DEM values and results from the analysis of aerial photographs. The set of reference points was expanded by additional reference points sampled from the $1700 \mathrm{~m}$ contour inferred to represent the highest lake level, and therefore the maximum elevation of the lake-sediment body. The irregularly spaced 3D reference points were interpolated onto a $100 \mathrm{~m} \times 100 \mathrm{~m}$ regular grid applying the Matlab ${ }^{\circledR}$ routine tspline (Wessel and Bercovici 1998). The sediment volume was calculated by subtracting top and base surfaces. In addition, the volume of the eroded material in the paleo-lake area after the termination of the paleolake was determined by subtraction of the sediment top and the modern topography. All results were tested for robustness by removing single reference points and recalculating sediment volume. Additional tests were done by varying interpolation methods (t-splines vs. conventional cubic 


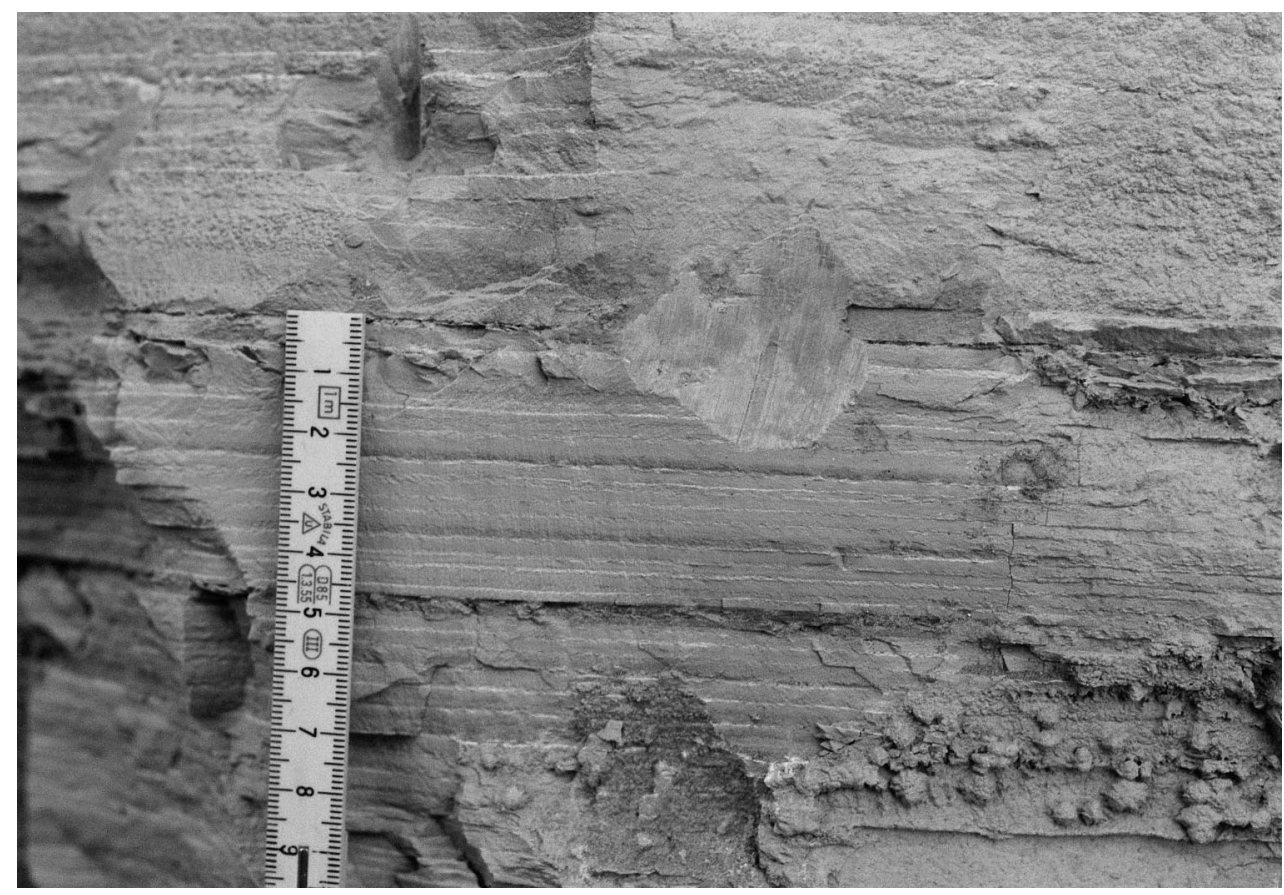

FIg. 4.-Photograph of varved lake sediments in the Santa Maria Basin with cyclic occurrence of intense dark-red coloration inferred to reflect enhanced precipitation and sediment input during ENSO- and TAV-type periodicities (350 $\mathrm{cm}$ above the base of the El Paso section).

splines and bilinear interpolation procedures) and the resolution of the DEM (from $25 \mathrm{~m}$ to $500 \mathrm{~m}$ ).

Landslide deposits were first located by analyzing Landsat TM scenes, using spectral bands 5, 4, and 2 by looking for their typical lobate forms in piedmont environments and spectral contrasts to valley deposits in narrow valley environments (Hermanns and Strecker 1999). In a second step, the inferred landslide origin of these deposits was verified on stereopairs of aerial photographs, which further helped to constrain landslides of different ages based on surface morphology. In a last step, around 90\% of the landslide sites were visited to study the geology of landslide-breakaway areas in detail, investigate the stratigraphic relations with associated lake sediments and fluvial deposits, and collect surface samples for cosmogenic nuclide dating (Hermanns et al. 2001), collect volcanic ashes for tephro- chronologic correlations and ${ }^{40} \mathrm{Ar} /{ }^{39} \mathrm{Ar}$ dating (e.g., Hermanns et al. 2000), and collect organic material for ${ }^{14} \mathrm{C}$ dating (Trauth and Strecker 1999; Trauth et al. 2000). The volumes of the landslides were determined using 3D measurements of their present-day distribution and applying standard techniques of modeling the original morphology of the deposits based on the DEM for the basin (for details see Hermanns and Strecker 1999; Hermanns et al. 2000; Hermanns et al. 2001).

Monthly precipitation data from 380 weather stations in the study area were used to calculate the spatial and temporal analysis of the present-day climate. These data include the Andean foreland regions between the towns of Tucuman, Salta, and Jujuy as well as intra-Andean valleys (Bianchi and Yañez 1992). Because the majority of the intra-Andean stations provide only rainfall measurements for the 1960 s, the data for 1966 were assumed

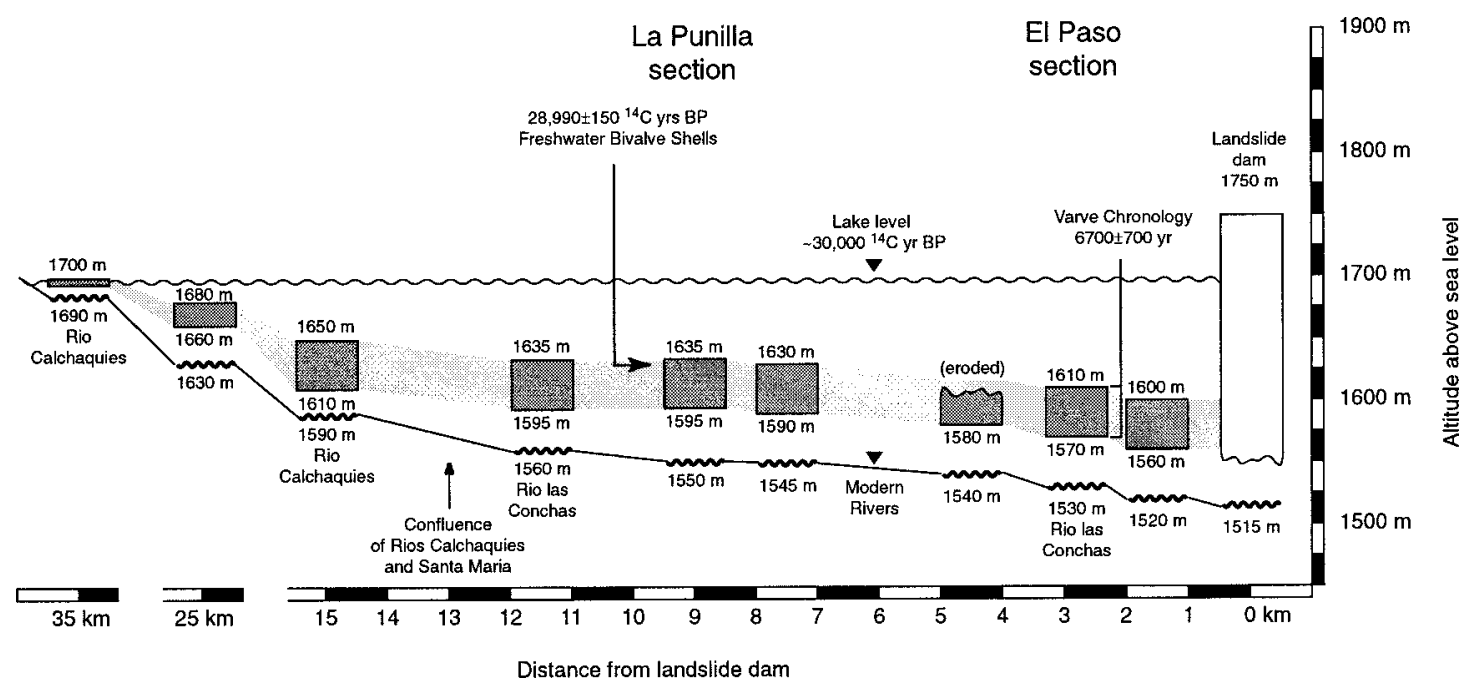

Fig. 5.-Cross section through the approximately $30,000{ }^{14} \mathrm{C}$ yr old lake-sediment body in the Santa Maria Basin with respect to the modern course of the Calchaquies and Las Conchas rivers. Radiocarbon age of the La Punilla section is from Trauth and Strecker (1999). Varve counts at El Paso section are from this work. 

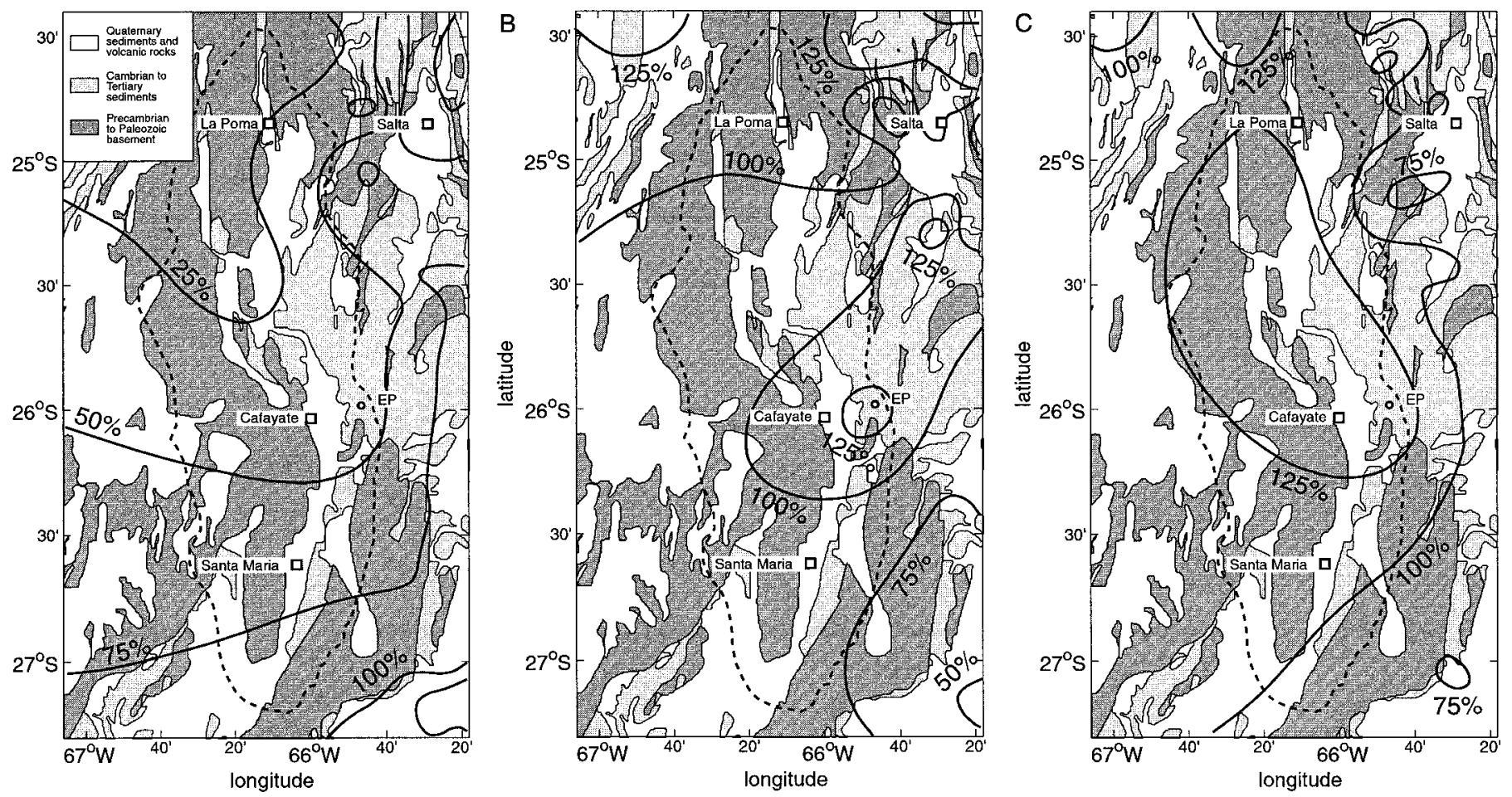

FIG. 6.-Simplified geologic map of the Santa Maria catchment showing the distribution of Quaternary sediments and volcanic rocks (white), sedimentary rocks of predominantly Cretaceous and Tertiary ages (light gray) and Precambrian to Paleozoic basement rocks (dark gray). The contours indicate rainfall anomalies during A) El Niño years, B) La Niña years, and C) minimum-TAV years expressed as percentage of annual rainfall as compared to mean-annual precipitation. Rainfall data are from Bianchi and Yañez (1992). Catchment area corresponds to black broken line.

to be representative for an El Niño year, data from 1965 were assumed to be typical of La Niña conditions, and 1963 was assumed to represent a minimum-strength TAV year. In order to evaluate the impact of ENSO and TAV on regional precipitation patterns, the ratio between annual precipitation for extreme ENSO or TAV years and the long-term average for each station was used. Comparisons with extreme years during other decades corroborate the observed spatial patterns in rainfall distributions (Trauth et al. 2000).

\section{RESULTS}

Using the above methodology, the total volume of the landslide deposits is approximately $1.1 \times 10^{9} \mathrm{~m}^{3}$, whereas the total sediment volume of the landslide-dammed lake amounts to $7.5 \times 10^{9} \mathrm{~m}^{3}$. However, several sources of uncertainties in the different steps of the calculation require further quality tests. It was found that removing single reference points and recalculating the sediment volume leads to negligible deviations from the above values. For example, after removing outliers and reference points of lesser quality, the deviation was smaller than $5 \%$. Slightly higher uncertainties were introduced by changing the gridding method. Gridding the elevation data by bilinear interpolation and the tspline routine yields sediment volumes between $9.3 \times 10^{9} \mathrm{~m}^{3}$ and $6.8 \times 10^{9} \mathrm{~m}^{3}$, respectively. The bilinear interpolation, however, leads to serious mathematical artifacts due to the highly irregular distribution of data points. Therefore, the value of $9.3 \times$ $10^{9} \mathrm{~m}^{3}$ was not considered; instead, the median of $7.5 \times 10^{9} \mathrm{~m}^{3}$ calculated from the results of varying interpolation routines and settings was used. The standard deviation of all computations with different gridding methods is on the order of $10 \%$. The error for the landslide volumes is hard to determine but most likely is even higher than $10 \%$.

The varve counts for these deposits cover a period of $6200 \mathrm{yr}$ and define an average sedimentation rate of $6.2 \pm 2.2 \mathrm{~mm} \mathrm{yr}^{-1}$ (Figs. 3 and 4). On top of the 37-m-thick varved profile at the outlet of the Santa Maria Basin, a loss on the order of three meters of sediment due to scouring at the base of a younger landslide is inferred. Sections in the immediate vicinity that are not covered by the younger landslide are $40 \mathrm{~m}$ thick and support this interpretation. Extrapolating the average sedimentation rate, three meters of additional sediment would increase the time interval of lacustrine deposition by approximately 500 yr. However, taking into account all uncertainties in the varve-based chronology, for example interruptions by turbidite and seismite layers, as well as problems in determining sediment loss on top of the profile, our best estimate for the duration of the lacustrine phase is $6700 \pm 700 \mathrm{yr}$.

Subtracting the $630-\mathrm{km}^{2}$ lake surface, the catchment area covers an area of $19,760 \mathrm{~km}^{2}$. Using the best estimate for the $7.5 \times 10^{9} \mathrm{~m}^{3}$ sediment volume, the catchment-averaged erosional volume is $7.5 \times 10^{9} \mathrm{~m}^{3} / 19,760$ $\mathrm{km}^{2}$, equaling $380 \mathrm{~mm}$ for the time period represented by the lake phase. Considering the uncertainty introduced by the various interpolation techniques, the erosion value could be as low as $340 \mathrm{~mm}$ and as high as 470 $\mathrm{mm}$. Assuming a total time span of $6700 \mathrm{yr}$ of erosion, the sediment yield provided by the catchment area is about $57 \mathrm{~mm} \mathrm{kyr}^{-1}$ or between 51 and $70 \mathrm{~mm} \mathrm{kyr}^{-1}$, using the different uncertainties. A typical density value for compacted lake sediments is $2.65 \mathrm{t} \mathrm{m}^{-3}$ (Einsele 2000). We used this value to make our data compatible with other studies on lacustrine sediments using this standard density. Therefore, total sediment mass flow is $7.5 \times$ $10^{9} \mathrm{~m}^{3} \times 2.65 \mathrm{t} \mathrm{m}^{-3} / 6700 \mathrm{yr}$, equaling $2.97 \times 10^{9} \mathrm{t} \mathrm{yr}^{-1}$. The erosion rate per square kilometer is $2.97 \times 10^{9} \mathrm{t} \mathrm{yr}^{-1} / 19,760 \mathrm{~km}^{2}$ or $150 \mathrm{t} \mathrm{yr}^{-1}$ $\mathrm{km}^{-2}$. Taking into account the potential errors, the erosion rate ranges between 135 and $185 \mathrm{t} \mathrm{yr}^{-1} \mathrm{~km}^{-2}$. The entire time span of enhanced massmovement activity in the Santa Maria Basin is not known, but it is likely that it corresponded to the duration of the Minchin wet phase, which probably started as early as $40,000{ }^{14} \mathrm{C}$ yr. In NW Argentina, the onset of this period of wetter climate may have started later and prevailed for a shorter time span since this region is located at the southern extremity of the spatial 
A

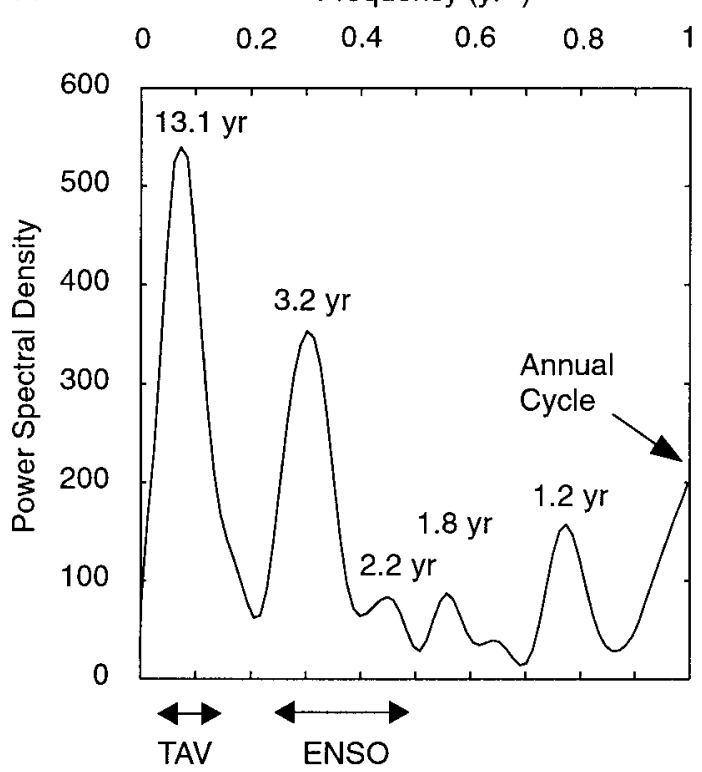

B

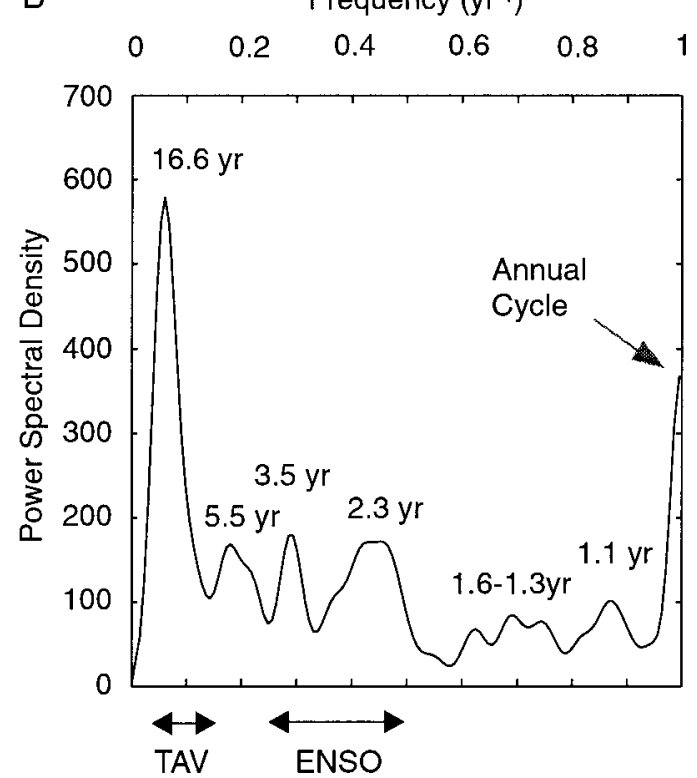

FIG. 7.-Power-spectrum estimate of a red-color intensity transect across A) 70 and B) 245 varves. Dominant frequency bands suggest a strong influence of the TAV, ENSO, and the seasonal cycle on local rainfall.

influence of this extreme climatic event. Assuming that the wetter conditions lasted for at least $7000 \mathrm{yr}$, which is the approximate time of the existence of the landslide-dammed lake, the corresponding erosion rate for the landslides is $23.0 \mathrm{t} \mathrm{yr}^{-1} \mathrm{~km}^{-2}$; the minimum contribution of rock avalanches for the full Minchin period would be on the order of $9.8 \mathrm{t} \mathrm{yr}^{-1}$ $\mathrm{km}^{-2}$.

The provenance of the lake sediments contained in the varved layers can be traced using index minerals characteristic of the catchment area (Figs. 4 and 6). All samples contain quartz, albite, potassium feldspar, illite, muscovite, chlorite, kaolinite, montmorillonite, vermiculite, and smaller amounts of hematite. Whereas the reddish clay and silt are rich in kaolinite, potassium feldspar, and hematite, the green-colored sediments contain higher amounts of chlorite and muscovite. The comparison of these mineral associations with the mineral content of source rocks in the catchment area indicates that $\mathrm{Fe}^{3+}$-rich Cretaceous and Tertiary sedimentary rocks in the valley regions were the principal source for the red-colored base of the varves. In contrast, Paleozoic metamorphic rocks in the mountainous parts of the catchment area were most likely the source of the drab-colored upper parts of the varves. Whereas the sedimentary rocks provide around 6470 $\mathrm{km}^{2}$ (or 33\%) of the catchment area, Paleozoic basement covers an area of $10,780 \mathrm{~km}^{2}(55 \%)$.

The bimodal character of varve composition suggests a yearly cycle of pronounced erosion in the basement-dominated source terrains of the uplands alternating with erosion of sedimentary rocks in the valley regions. The peculiar sediment pattern in the varves correlates with present variations in rainfall patterns (Trauth and Strecker 1999), where today the intensity of precipitation within a given area fluctuates by more than a factor of two. Potential sources for this variability are the ENSO and TAV precipitation teleconnections (Trauth et al. 2000). Rainfall during an El Niño event is, for example, anomalously low in the intra-Andean part of the study area, whereas rainfall amounts are significantly higher in the Andean foreland (Fig. 6A). During El Niño years, most stations in the intramontane Santa Maria Basin receive less than 50\% of the mean-annual rainfall value. In contrast, regions in the southeastern part of the study area as well as in the eastern foreland of the Andes receive more than $125 \%$ of the normal value during El Niño years. Similar results, but with an opposite sign, characterize La Niña events (Fig. 6B). Whereas mountainous regions re- ceive higher precipitation, the foreland experiences reduced rainfall. However, the amplitude of these spatial anomalies is smaller than the corresponding anomalies during an El Niño event. The major part of the study area shows only a weak La Niña response, i.e., values are not substantially different from the mean annual precipitation. Interestingly, large areas covered with Cretaceous and Tertiary sedimentary rocks receive higher amounts of rainfall than average during these years. Also the northwestern mountain regions receive higher amounts of rainfall during La Niña events. The Tropical Atlantic SST Variability seems to consistently increase rainfall in NW Argentina (Fig. 6C). Especially in the mountain regions, rainfall is locally significantly higher by a factor of two. Similarly to the La Niña precipitation pattern, rainfall is increased in regions with predominant Cretaceous and Tertiary sediments.

The power-spectrum estimate of a red-color intensity transect over 70 varves reveals significant peaks at 13.1, 3.2,2.2, and around $1.0 \mathrm{yr}$, whereas the full record of 245 varves shows peaks at 16.6, 5.5, 3.5, 2.3, and $1.0 \mathrm{yr}$ (Fig. 7). This suggests a strong interannual influence from both the ENSO and the TAV in addition to the seasonal precipitation changes. Comparable varved sections in the higher parts of the profile show similar but less regular cyclicities. The increase in the annual sedimentation rate during the wetter years is between 30 and $60 \%$. Integrating the higher sediment flux over a longer time span, there is a 10 to $15 \%$ increase during times of a stronger ENSO or TAV as compared to periods of absent or weak influence of these oscillations. In particular, the amount of chlorite and muscovite derived from metamorphic rocks does not change from varve to varve, but the amounts of kaolinite, potassium feldspar, and hematite derived from Fe-rich Cretaceous and Tertiary sedimentary rocks increase significantly during wetter years. This suggests that the sediment supply from the highrelief areas is more or less constant, whereas La Niña and minimum TAV years cause higher erosion and sedimentation in those low-relief parts of the catchment dominated by sedimentary rocks.

\section{DISCUSSION}

We compared the sediment budget of the Santa Maria Basin for a period of significantly wetter and more variable climate at around $30,000{ }^{14} \mathrm{C} \mathrm{yr}$ $\mathrm{BP}$ with the modern sediment flux in order to test the hypothesis that 


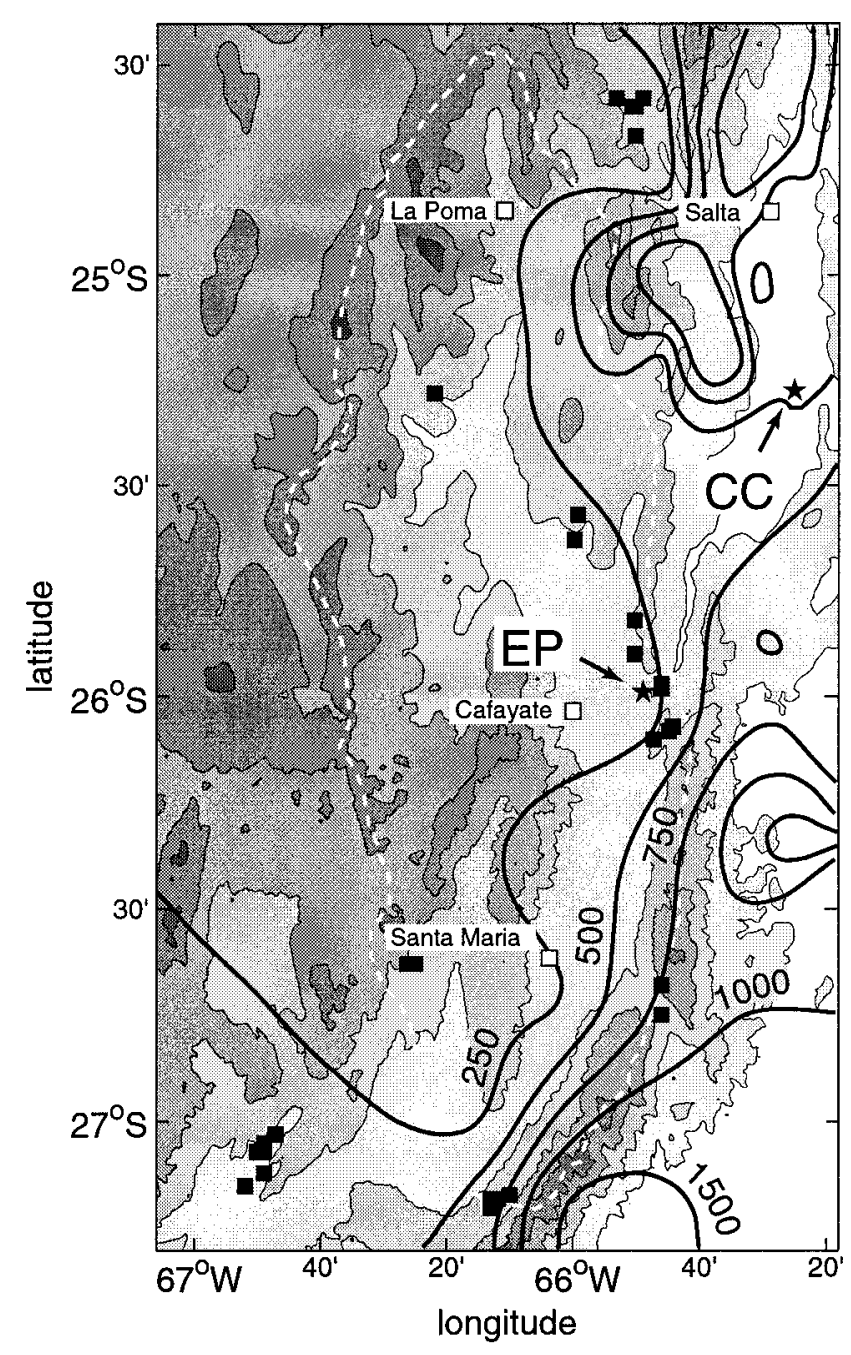

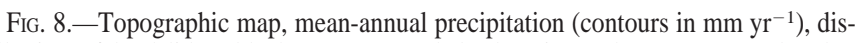
tribution of landslides (black squares), and the locations El Paso (EP) and Cabra Corral (CC), where erosional budgets were determined. Rainfall data are from Bianchi and Yañez (1992). Landslide locations are from Strecker et al. (1989) and Hermanns and Strecker (1999).

Quaternary climate changes significantly influenced erosion in this semiarid region. In the semiarid intra-Andean basins, long-term mechanical denudation with low rates and episodic landsliding with extreme mass-transfer rates are the most important erosional processes (Hermanns and Strecker 1999; Strecker and Marrett 1999; Trauth and Strecker 1999; Hermanns et al. 2000; Trauth et al. 2000).

The volume of the lake-sediment body that accumulated behind the landslide dam during a time span of 7000 yr during the late Pleistocene Minchin wet phase is around $7.5 \mathrm{~km}^{3}$ (Fig. 8). The sediment yield with respect to the $19,760 \mathrm{~km}^{2}$ catchment during that time has been calculated as between 135 and $185 \mathrm{t} \mathrm{yr}^{-1} \mathrm{~km}^{-2}$. Typical mechanical denudation rates for arid and semiarid basins draining areas of very high relief vary between 100 and $300 \mathrm{t} \mathrm{yr}^{-1} \mathrm{~km}^{-2}$ (e.g., Einsele 2000), but unfortunately no modern measurements of sediment flux for the Santa Maria Basin are available. However, for the next larger basin downstream, the Lerma Basin, with a catchment of about $32,000 \mathrm{~km}^{2}$, precise measurements of sediment load at the location of the Cabra Corral dam suggest erosion rates between 300 and $600 \mathrm{t} \mathrm{yr}^{-1} \mathrm{~km}^{-2}$ (Agua y Energia 1991; Malamud et al. 1996) (Fig. 9). The Lerma Basin is located east of the orographic rainshadow with local rainfall in excess of $1500 \mathrm{~mm} \mathrm{yr}^{-1}$. Therefore, relatively small catchments

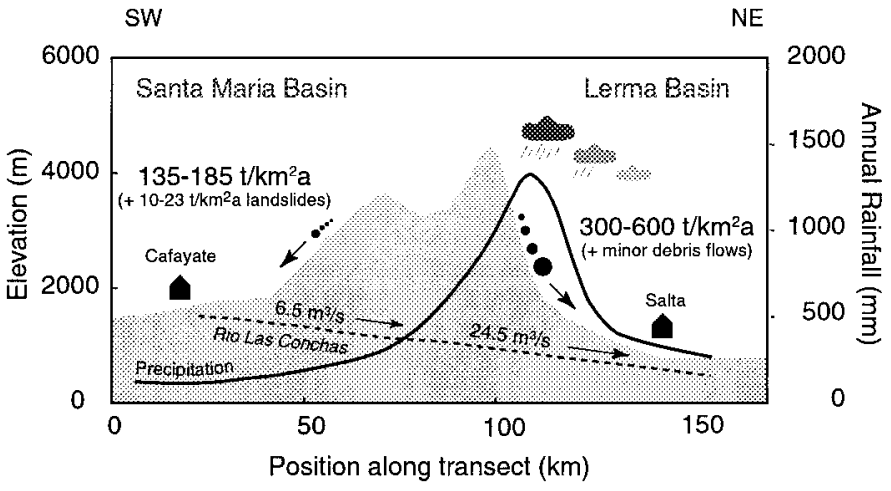

FIG. 9.- Transect from the Santa Maria Basin to the Lerma Basin across the southernmost extension of the Cordillera Oriental orographic barrier. Basin-averaged precipitation and river discharge increase by a factor of four, whereas sediment flux increases by a factor of three in the eastward direction. The enormous gradient in erosion of $60 \mathrm{t} \mathrm{km}^{-2} \mathrm{a}^{-1}$ per $10 \mathrm{~km}$ could cause an asymmetric uplift of mountain ranges due to constant erosional unloading in the area of active thrusting.

on the order of $7100 \mathrm{~km}^{2}$ have an averaged discharge of $24.4 \mathrm{~m}^{3} \mathrm{~s}^{-1}$ (San Gabriel) whereas at the outlet of the Santa Maria Basin this value is only $6.5 \mathrm{~m}^{3} \mathrm{~s}^{-1}$ (Agua y Energia 1991). Taking into account the higher precipitation value for the Lerma Basin, the sediment yield between 300 and 600

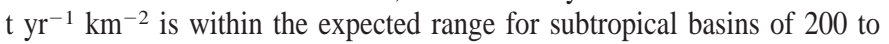
$500 \mathrm{t} \mathrm{yr}^{-1} \mathrm{~km}^{-2}$, according to Einsele (2000). No major rock avalanches are reported from this humid environment. However, minor debris flows occasionally occur at the eastern flanks of the mountain ridges west of the Lerma Basin. Voluminous rock avalanches are a typical feature only of the semiarid intra-Andean basins and valleys, such as the Santa Maria Basin.

Despite the fact that no data on modern sediment load for the Santa Maria Basin exist, it seems reasonable that the calculated value of 135 and $185 \mathrm{t} \mathrm{yr}^{-1} \mathrm{~km}^{-2}$ does not represent an anomalously high value that can be attributed to a dramatically different, much more effective erosion regime during the Minchin wet period. Because the climatic conditions during this interval represent the upper limit for Quaternary humidity phases in the Central Andes, it is unlikely that climate fluctuations during the last million years fundamentally changed sediment transfer rates in this environment. This could be partly attributed to the fact that the environmental changes on a regional scale are rather small. The basin-averaged precipitation value during this time is known from lake-balance modeling (Bookhagen et al. 2001). A surplus in rainfall and discharge of 10 to 15 percent apparently were not high enough to cause a measurable increase in basin-wide erosion and sediment flux. The most sensitive areas for such climatic changes are the mountainous regions, roughly between the modern 250 and $500 \mathrm{~mm}$ $\mathrm{yr}^{-1}$ contours. In the mountains and the deep valleys, a change in vegetation, especially a westward shift of the tree-covered areas, is the most obvious consequence of increased moisture transport from the NE and $\mathrm{E}$ into the dry Andean valleys. Such changes are recorded in the pollen assemblages preserved in the lacustrine sediments, again suggesting significant changes around 15 to $20 \mathrm{~km}$ east of the Santa Maria Basin, whereas the basin itself did not experience significant changes in precipitation and in vegetation cover (Trauth and Strecker 1999; F. Schäbitz, personal communication). Increased discharge of the rivers draining the mountainous regions, however, must have led to enhanced but very localized erosion along the courses of the streams.

Nonlinear time-series analysis on the varved lake deposits in the Santa Maria Basin shows that the rainy season during the Minchin wet period between 40,000 and $25,000{ }^{14} \mathrm{C}$ yr BP was indeed longer than at present (Marwan et al. 2000). These analyses also showed that the influence of the El Niño/Southern Oscillation on local rainfall must have been much stronger than today. Especially the La Niña phase of the ENSO caused heavier 
rainfalls and discharge with modern ENSO-type cyclicities. From detailed provenance analysis on varved lake sediments we found a 10 to $15 \%$ increase in erosion and sedimentation caused by a stronger ENSO influence, which is attributed mainly to enhanced erosion of Cretaceous and Tertiary sediments in the lower parts of the basin, whereas extreme ENSO events did not affect the high-altitude areas of the catchment. It is inferred that this wetter and more seasonal climate also resulted in increased mass-movement activity in the Central Andes (Hermanns et al. 2000; Trauth et al. 2000). In the basin catchment area, Hermanns et al. (1999) mapped 18 landslides with volumes between 35 and $220 \times 10^{6} \mathrm{~m}^{3}$. New age data suggest that twelve of these rock avalanches occurred during the Minchin wet period (Hermanns et al. 2000). However, the landslide deposits in NW Argentina are restricted to certain geomorphic settings (Hermanns and Strecker 1999): vertical relief contrasts between the breakaway zone and the mountain front are in excess of $400 \mathrm{~m}$, and slope inclinations must be steeper than $20^{\circ}$. There are also lithologic constraints, because large landslides are restricted to granites, low-grade metamorphic rocks, and coarse clastic sediments. In addition, major slide clusters occur along fault-bounded mountain fronts with recurrent Quaternary tectonic activity. In addition, the landslides in the Santa Maria Basin are restricted to a narrow sector between the present 250 and $500 \mathrm{~mm} \mathrm{yr}^{-1}$ precipitation contours (Fig. 8). These are the most sensitive areas for climatic changes and erosion where rivers undercut mountain fronts and create deep valleys and gullies in areas where no dense vegetation cover is present. The overall contribution of these mass movements to the total erosional budget of the Santa Maria Basin, however, is less. Much of the landslide material was not removed from the basin, because it was prevented from erosion due to the aridity. This restriction, however, mainly applies to the voluminous landslide deposits on broad alluvial-fan-covered piedmonts located far away from trunk streams. In contrast, most of the lake sediments and associated landslide deposits along trunk stream areas have been eroding since $30,000{ }^{14} \mathrm{C} \mathrm{yr}$ $\mathrm{BP}$, with high rates of up to $5 \times 10^{3} \mathrm{t} \mathrm{yr}^{-1} \mathrm{~km}^{-2}$.

The total volume of these avalanche deposits is approximately $1.1 \times$ $10^{9} \mathrm{~m}^{3}$. The error for this number is hard to determine, but most likely larger than $10 \%$. In addition, the time span of enhanced mass movements in the basin is not known but most likely was between 7000 yr (i.e., the time of existence of the lake) and 15,000 $\mathrm{yr}$ (the duration of the Minchin period; van der Hammen and Absy 1994; Wirrmann and Mourguiart 1995; Ledru et al. 1996; Godfrey et al. 1997; Turcq et al. 1997). In NW Argentina, the onset of the Minchin wet period may have started later and prevailed for a shorter time span, because this region is located at the southern extremity of the spatial influence of this extreme climatic event. Assuming that the wetter conditions lasted for at least $7000 \mathrm{yr}$, the corresponding erosion rate for the landslides is $23.0 \mathrm{t} \mathrm{yr}^{-1} \mathrm{~km}^{-2}$; the minimum contribution of rock avalanches for the full Minchin period would be on the order of $9.8 \mathrm{t} \mathrm{yr}^{-1} \mathrm{~km}^{-2}$. These data suggest that the contribution to the sedimentary budget by mass movements is of the same order of magnitude as the long-term background sediment yield. This is in line with the results of Keefer (1994) who compared seismically triggered mass movements and all other erosional mechanisms in several basins of the world. In some environments, however, the contribution of catastrophic mass movements exceed the contributions of other erosion mechanisms to sedimentary budgets (Keefer 1994).

In summary, a more variable climate due to a stronger ENSO influence in the largest intra-Andean Basin in NW Argentina increased both the longterm background erosion and the landslide activity. The contribution of these erosional mechanisms to the erosional budget is 10 to $15 \%$ each. This value is significant, but small and affected with errors of the same order of magnitude. The most dramatic change in erosion due to shifts of rainfall anomalies is located in a corridor, 25 to $35 \mathrm{~km}$ wide, between the present 250 and $500 \mathrm{~mm} \mathrm{yr}^{-1}$ precipitation contours. This is also the area where the largest landslides occur, and where the only influence of climate changes on tectonic style, uplift rates, and changes in relief could be expected.

\section{CONCLUSIONS}

The most effective erosional mechanism in semiarid intra-Andean basins is a highly variable climate on interannual timescales, which triggers enhanced mass movements. In contrast, Quaternary changes in erosional budgets due to variations in moisture regimes is small. Although the influence of climate on the overall erosional sediment budget in the semiarid Santa Maria Basin is significant, the magnitude of a potential increase in background erosion as well as enhanced landsliding is smaller than uncertainties in erosional budgets for such large basins. Therefore it is not likely that climate-driven erosional unloading can influence tectonic style and rates in this semiarid environment on time scales of several thousands to a few tens of thousands of years.

\section{ACKNOWLEDGMENTS}

This work is part of the Collaborative Research Center 267 " Deformation Processes in the Andes" supported by the German Research Foundation. The success of this project was made possible through the support of many Argentine friends and colleagues, namely R. Alonso, J.A. Salfity, and R. Gonzales. We also thank editor M. Kraus, the two reviewers M. Blum and F. Pazzaglia and corresponding editor J. Southard for their helpful comments on the manuscript. Varve counts were carried out by D. Oberst. Total station measurements were carried out with the help of S. Sillmann. We thank E. Sobel and R. Hermanns for fruitful discussions.

\section{REFERENCES}

Anderson, R.Y., 1996, Seasonal sedimentation: a framework for reconstructing climate and environmental change, in Kemp, A.E.S., ed., Palaeoclimatology and Palaeoceanography from Laminated Sediments: Geological Society of London, Special Publication 116, p. $1-15$.

Agua y Energia, 1991, Estadística Hidrológica hasta 1990, Sedimentología, Tomo II: Buenos Aires, Argentina, Gerencia de Ingenieria, 300 p.

Beaufort, L., de Garidel-Thoron, T., Mix, A.C., and Pisias, N.G., 2001, ENSO-like forcing on oceanic primary production during the late Pleistocene: Science, v. 293, p. 2440-2444.

Bianchi, A.R., AND YAÑEZ, C.E., 1992, Las precipitaciones en el noroeste Argentino: Salta, Argentina, Instituto Nacional de Tecnología Agropecuaria, Estación Experimental Agropecuaria, $383 \mathrm{p}$.

Bookhagen, B., Haselton, K., and Trauth, M.H., 2001, Hydrological modeling of a Pleistocene landslide-dammed lake in the Santa Maria Basin, NW Argentina: Palaeogeography, Palaeoclimatology, Palaeoecology, v. 169, p. 113-127.

Bossi, G.E., and Palma, R.M., 1982, Reconsideración de la estratigrafía del Valle de Santa Maria, Provincia de Tucumán, Argentina: V Congreso Latinoamericano de Geología Actas, v. 1 , p. $153-171$

Bull, W.B., 1991, Geomorphic Responses to Climatic Change: Oxford, U.K., Oxford University Press, $326 \mathrm{p}$.

Chang, P., Ji, L., And Li, H., 1997, A decadal climate variation in the tropical Atlantic Ocean from thermodynamic air sea interactions: Nature, v. 385, p. 516-518.

Einsele, G., 2000, Sedimentary Basins, Evolution, Facies and Sediment Budget: Berlin, Springer, $792 \mathrm{p}$.

Einsele, G., AND Hinderer, M., 1998, Quantifying denudation and sediment-accumulation systems, open and closed lakes: basic concepts and first results: Palaeogeography, Palaeoclimatology, Palaeoecology, v. 140, p. 7-21.

ENFIELD, D.B., AND MAYER, D.A., 1996, Tropical Atlantic SST variability and its relation to El Niño/Southern Oscillation: Journal of Geophysical Research, v. 102, p. 929-945.

Fox, A.N., ANd StReCKer, M.R., 1991, Pleistocene and modern snowlines in the Central Andes $\left(24-28^{\circ} \mathrm{S}\right)$ : Bamberger Geographische Schriften, v. 11, p. 169-182.

Godfrey, L.V., Lowenstein, T.K., Li, J., Luo, S., Ku, T.-L., Alonso, R.N., and Jordan, T.E., 1997, Regístro Continuo del Pleistocene Tardio Basado en un Testigo de Halita del Salar de Hombre Muerto, Argentina: VIII Congreso Geologico Chileno, v. 1, p. 332-336.

Grier, M., Salfity, J., And Allmendinger, R., 1991, Andean reactivation of the Cretaceous Salta Rift, NW Argentina: Journal of South American Earth Sciences, v. 4, p. 331-342.

Grosjean, M., Núñez, L., Cartajena, I., and Messerli, B., 1997, Mid-Holocene climate and culture change in the Atacama Desert, Northern Chile: Quaternary Research, v. 48, p. 239246.

Haselton, K., Hilley, G., and Strecker, M.R., 2002, Average Pleistocene climatic patterns in the southern Central Andes: Controls on mountain glaciation and paleoclimate implications: Journal of Geology, v. 110, p. 211-226.

Hastenrath, S., 1991, Climate Dynamics of the Tropics: Dordrecht, The Netherlands, Kluwer Academic Publishers, 488 p.

Hermanns, R.L., Niedermann, S., Villanueva, A., Sosa Gomez, J., and Strecker, M.R., 2001, Neotectonics and catastrophic failure of mountain fronts in the southern intra-Andean Puna Plateau: Geology, v. 29, p. 619-623.

Hermanns, R.L., AND StReCKer, M.R., 1999, Structural and lithological controls on large Quaternary rock avalanches, sturzstroms, in arid northwestern Argentina: Geological Society of America, Bulletin, v. 111(6), p. 934-948. 
Hermanns, R., Trauth, M.H., McWilliams, M., and Strecker, M.R., 2000, Tephrochronologic constraints on temporal distribution of large landslides in NW-Argentina: Journal of Geology, v. 108, p. 35-52.

KeEFER, D.K., 1994, The importance of earthquake-induced landslides to long-term slope erosion and slope-failure hazards in seismically active regions: Geomorphology, v. 10, p. 265 284.

KeEFER, D.K., 1999, Earthquake-induced landslides and their effects on alluvial fans: Journal of Sedimentary Research, v. 69, p. 84-104.

Keefer, D.K., deFrance, S.D., Moseley, M.E., Richardson, J.B., Satterlee, D.R., and DayLewIs, A., 1998, Early maritime economy and El Niño events at Quebrada Tacahuay, Peru: Science, v. 281, p. 1833-1835.

KILADIS, G.N., AND Diaz, H.F., 1989, Global climatic anomalies associated with extremes of the Southern Oscillation: Journal of Climate, v. 2, p. 1069-1090.

Ledru, M.P., Braga, P.I.S., Soubiès, F., Fournier, M., Martin, L., Suguio, K., and TurcQ, B., 1996, The last 50,000 years in the Neotropics, Southern Brazil: evolution of vegetation and climate: Palaeogeography, Palaeoclimatology, Palaeoecology, v. 123, p. 239-257.

Malamud, B.D., Jordan, T.E., Alonso, R.A., Gallardo, E.F., Gonzalez, R.E., and Kelley, S.A., 1996, Pleistocene lake Lerma, Salta Province, NW Argentina: 13th Congreso Geológico Argentino y 3d Congreso Exploración Hidrocarbónica, Actas, v. 4, p. 103-114

Marwan, N., Trauth, M.H., Schwarz, U., Kurths, J., and Strecker, M.R., 2000, ENSO impact on landslide generation in northwestern Argentina (abstract): Geophysical Research Abstracts, v. 2, p. 317.

Marwan, N., AND Kurths, J., 2002, Nonlinear analysis of bivariate data with cross recurrence plots: Physics Letters A, 302(5-6), p. 299-307.

Molnar, P., And England, P., 1990, Late Cenozoic uplift of mountain ranges and global climate change: Chicken or egg? Nature, v. 346, p. 29-34.

Molnar, P., England, P., and Martinod, J., 1993, Mantle dynamics, uplift of the Tibetan Plateau, and the Indian monsoon: Reviews of Geophysics, v. 31, p. 357-396.

Mulder, T., ANd Syvitski, J.P.M., 1996, Climatic and morphologic relationships of rivers: Implications of sea-level fluctuations on river loads: Journal of Geology, v. 104, p. 509523.

Prohaska, F.J., 1976, The climate of Argentina, Paraguay and Uruguay, in Schwerdtfeger, W., ed., Climates in Central and South America: World Survey of Climatology, v. 12, p. $13-73$.

Raymo, M.E., 1994, The Himalayas, organic carbon burial, and climate in the Miocene: Paleoceanography, v. 9, p. 399-404.
Raymo, M.E., and Ruddiman, W.F., 1992, Tectonic forcing of late Cenozoic climate: Nature, v. 359, p. $117-122$.

ROPELEWSKI, C.F., AND HALPERT, M.S., 1987, Global and regional scale precipitation pattern associated with the El Niño/Southern Oscillation: Monthly Weather Review, v. 115, p $1606-1626$

Ruddiman, W., 1997, Tectonic Uplift and Climate Change: Dordrecht, The Netherlands, Kluwer Academic Publishers, $558 \mathrm{p}$.

Small, E., 1999, Does global cooling reduce relief?: Nature, v. 401, p. 31-32.

Strecker, M.R., Cerveny, P., Bloom, A.L., and Malizzia, D., 1989, Late Cenozoic tectonism and landscape development in the foreland of the Andes: Northern Sierras Pampeanas, $26^{\circ}$ $28^{\circ} \mathrm{S}$ ), Argentina: Tectonics, v. 8, p. $517-534$

Strecker, M.R., AND Marrett, R., 1999, Kinematic evolution of fault ramps and its role in development of landslides and lakes in the northwestern Argentine Andes: Geology, v. 27(4), p. 307-310

Trauth, M.H., AND Strecker, M.R., 1999, Formation of landslide-dammed lakes during a wet period between 40,000 and 25,000 yr B.P. in northwestern Argentina: Palaeogeography, Palaeoclimatology, Palaeoecology, v. 153(1-4), p. 277-287.

Trauth, M.H., Alonso, R.A., Haselton, K.R., Hermanns, R.L., and Strecker, M.R., 2000, Climate change and mass movements in the northwest Argentine Andes: Earth and Planetary Science Letters, v. 179, p. 243-256.

Tudhope, A.W., Chilcott, C.P., McCulloch, M.T., Сook, E.R., Chappell, J., Ellam, R.M., LEA, D.W., Lough, J.M., And Shimmield, G.B., 2001, Variability in the El Niño/Southern Oscillation through a glacial-interglacial cycle: Science, v. 291, p. 1511-1517.

TurcQ, B., Pressinotti, M.M.N., and Martin, L., 1997, Paleohydrology and paleoclimate of the past 33,000 years at the Tamaduá River, central Brazil: Quaternary Research, v. 47, p 284-294.

van der Hammen, T., And Absy, M.L., 1994, Amazonia during the last glacial: Palaeogeography, Palaeoclimatology, Palaeoecology, v. 109, p. 247-261.

Wessel, P., AND Bercovici, D., 1998, Interpolation with splines in tension: A Green's function approach: Mathematical Geology, v. 30, p. 77-93.

Willett, S.D., Slingerland, R., and Hovius, N., 2001, Uplift, shortening, and steady-state topography in active mountain belts: American Journal of Science, v. 301, p. 455-485.

WirRmann, D., AND Mourguiart, P., 1995, Late Quaternary spatio-temporal limnological variations in the Altiplano of Bolivia and Peru: Quaternary Research, v. 43, p. 344-354.

Whipple, K.X., Kirby, E., and Brocklehurst, S.H., 1999, Geomorphological limits to climateinduced increases in topographic relief: Nature, v. 401, p. 39-43.

Received 19 June 2001; accepted 17 June 2002 